\title{
Virgibacillus sediminis sp. nov., a moderately halophilic bacterium isolated from a salt lake in China
}

Correspondence

Xiao-Long Cui

xlcuiynu@yahoo.com.cn

or

xlcui@ynu.edu.cn

\author{
Yi-Guang Chen, ${ }^{1,2}$ Xiao-Long Cui, ${ }^{1}$ Yong-Xia Wang, ${ }^{1}$ Yu-Oin Zhang, ${ }^{1,3}$ \\ Shu-Kun Tang, ${ }^{1}$ Wen-Jun Li, ${ }^{1}$ Zhu-Xiang Liu, ${ }^{2}$ Meng-Liang Wen ${ }^{1}$ \\ and Qian Peng ${ }^{1}$
}

\author{
${ }^{1}$ Yunnan Institute of Microbiology, Yunnan University, Kunming, Yunnan 650091, PR China \\ ${ }^{2}$ Key Laboratory for Conservation and Utilization of Plant Resources of Hunan Province, College of \\ Biology and Environmental Sciences, Jishou University, Jishou, Hunan 416000, PR China \\ ${ }^{3}$ Institute of Medicinal Biotechnology, Chinese Academy of Medical Sciences \& Peking Union \\ Medical College, Beijing 100050, PR China
}

\begin{abstract}
A Gram-positive, moderately halophilic, alkalitolerant, strictly aerobic, oxidase- and catalasepositive, rod-shaped bacterium, strain $\mathrm{YIM} \mathrm{kkny}^{\top}$, was isolated from a sediment sample collected from a salt lake in the Qaidam Basin of north-west China. Cells were motile by means of peritrichous flagella and formed ellipsoidal endospores lying in subterminal swollen sporangia. Growth occurred with 1-20\% (w/v) total salts (optimum, 5-10\%) and at pH 6.0-10.5 (optimum, $\mathrm{pH} 7.5-8.0$ ) and $10-55^{\circ} \mathrm{C}$ (optimum, $35-40{ }^{\circ} \mathrm{C}$ ). It was unable to grow with $\mathrm{NaCl}$ as the only salt. meso-Diaminopimelic acid was present in the cell-wall peptidoglycan. The strain contained menaquinone 7 (MK-7) as the predominant respiratory quinone and diphosphatidylglycerol, phosphatidylglycerol, phosphatidylethanolamine and an unidentified phospholipid as polar lipids. The major cellular fatty acids were anteiso- $C_{15: 0}$ and anteiso- $C_{17: 0}$. The DNA G $+C$ content was $40.9 \mathrm{~mol} \%$. Phylogenetic analysis based on 16S rRNA gene sequences indicated that strain YIM kkny3 ${ }^{\top}$ belonged to the genus Virgibacillus, and was most closely related to the type strains of Virgibacillus olivae (97.1\% similarity), Virgibacillus marismortui (97.0\%) and Virgibacillus kekensis $(96.8 \%)$. Levels of DNA-DNA relatedness between strain YIM kkny3 ${ }^{\top}$ and the type strains of $V$. olivae, V. marismortui and $V$. kekensis were 12.4, 10.6 and $15.7 \%$, respectively. The combination of phylogenetic analysis, genotypic data, phenotypic characteristics and chemotaxonomic differences indicated that strain YIM kkny3 ${ }^{\top}$ represents a novel species of the genus Virgibacillus, for which the name Virgibacillus sediminis sp. nov. is proposed. The type

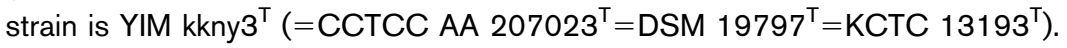

The genus Virgibacillus was proposed by Heyndrickx et al. (1998). At the time of writing, the genus comprised 13 recognized species: Virgibacillus pantothenticus (Heyndrickx et al., 1998), V. proomii (Heyndrickx et al., 1999), V. carmonensis, V. necropolis, V. marismortui and $V$. salexigens (Heyrman et al., 2003), V. halodenitrificans (Yoon et al., 2004), V. dokdonensis (Yoon et al., 2005), V. koreensis (Lee et al., 2006), V. olivae (Quesada et al., 2007),

The GenBank/EMBL/DDBJ accession number for the 16S rRNA gene sequence of strain $\mathrm{YIM}$ kkny3 ${ }^{\top}$ is $A Y 121430$.

Maximum-parsimony and minimum-evolution phylogenetic trees based on $16 \mathrm{~S}$ rRNA gene sequences showing the position of strain YIM $k$ kny $3^{\top}$ among its closest neighbours, and a table giving the whole-cell fatty acid profiles of strain YIM kkny3 ${ }^{\top}$ and recognized species of the genus Virgibacillus are available with the online version of this paper.
V. halophilus (An et al., 2007), V. chiguensis (Wang et al., 2008) and V. kekensis (Chen et al., 2008a). During a recent study of the microbial diversity of the Qaidam Basin in Qinghai Province, north-west China (Chen et al., 2007a, 2008a, b, c, d), a moderately halophilic bacterium, designated strain YIM kkny3 ${ }^{\mathrm{T}}$, was isolated from a sediment sample collected from the Keke salt lake in August 2002. The lake is located at $36^{\circ} 18^{\prime}-36^{\circ} 55^{\prime} \mathrm{N}$ $99^{\circ} 02^{\prime}-99^{\circ} 12^{\prime} \mathrm{E}$; the lake water was at $18^{\circ} \mathrm{C}$, had a $\mathrm{pH}$ of $6.5-7.5$ and had a salinity of $298 \mathrm{~g} \mathrm{l}^{-1}$. Based on the results of the present polyphasic taxonomic study, strain YIM kkny $3^{\mathrm{T}}$ is considered to represent a novel species of the genus Virgibacillus.

Strain YIM kkny $3^{T}$ was isolated from a saline sediment sample by plating $1: 10$ serial dilutions of the sample on 
Difco marine agar 2216 (MA) supplemented with 5\% (w/v) $\mathrm{NaCl}$ [containing approximately $7 \% \mathrm{NaCl}$ and $8.4 \%$ total salts (hereafter referred to as MA5); $\mathrm{pH} 7.5]$ at $37{ }^{\circ} \mathrm{C}$ for 2 weeks. After primary isolation and purification, the isolate was kept as serial transfers on slants of MA5, as lyophilized cultures at $4{ }^{\circ} \mathrm{C}$, or deep-frozen at $-80{ }^{\circ} \mathrm{C}$ in Difco marine broth 2216 (MB) supplemented with $5 \%$ (w/v) $\mathrm{NaCl}$ and $20 \%(\mathrm{v} / \mathrm{v})$ glycerol. Three reference strains, $V$. marismortui DSM $12325^{\mathrm{T}}, V$. halodenitrificans DSM $10037^{\mathrm{T}}$ and $V$. kekensis YIM kkny $16^{\mathrm{T}}$, were obtained from the DSMZ (Deutsche Sammlung von Mikroorganismen und Zellkulturen) and the YIM (Yunnan Institute of Microbiology). Unless otherwise indicated, morphological and physiological studies were performed with cells grown on MA5 ( $\mathrm{pH} 7.5$ ) at $37^{\circ} \mathrm{C}$. Cell morphology was examined by light microscopy (model $\mathrm{BH} 2$; Olympus). Gram staining was carried out by using the standard Gram reaction (Doetsch, 1981) combined with the $\mathrm{KOH}$ lysis test method (Gregersen, 1978). Flagella and endospores were stained according to the methods of Leifsson and Schaeffer-Fulton, respectively (Smibert \& Krieg, 1994). For endospore observation, the novel strain was grown on MA5 supplemented with $10 \mathrm{mg} \mathrm{MnSO}_{4}$ for 2 days at $30{ }^{\circ} \mathrm{C}$ and 7 days at room temperature $\left(18-20^{\circ} \mathrm{C}\right)$. Growth was tested at $5-60{ }^{\circ} \mathrm{C}$ (at increments of $5{ }^{\circ} \mathrm{C}$ ) on MA5 and at $\mathrm{pH}$ 5.0-11.0 (with increments of $0.5 \mathrm{pH}$ units) on MA5 and in $\mathrm{MB}$ supplemented with $5 \%(\mathrm{w} / \mathrm{v}) \mathrm{NaCl}$. Growth at different total salt concentrations [0 and $0.5 \%(\mathrm{w} / \mathrm{v})$ and $1-$ $30 \%(\mathrm{w} / \mathrm{v})$ at increments of $1 \%$ ] was determined on MA, prepared according to the formula of Atlas (1993). Growth was also tested with $\mathrm{NaCl}$ as the sole salt. Tests for methyl red, the Voges-Proskauer reaction, $\mathrm{H}_{2} \mathrm{~S}$ and indole production, hydrolysis of aesculin, nitrate and nitrite reduction were performed as recommended by Smibert \& Krieg (1994). Hydrolysis of casein, gelatin, starch, Tweens (20, 40, 60 and 80) and urea were determined as described by Cowan \& Steel (1965). Growth under anaerobic conditions was determined on MA and in MB supplemented with $5 \%(\mathrm{w} / \mathrm{v}) \mathrm{NaCl}$ and with or without $0.5 \%$ $(\mathrm{w} / \mathrm{v})$ glucose or $0.1 \%(\mathrm{w} / \mathrm{v})$ nitrate, by using the GasPak Anaerobic System (BBL) according to the manufacturer's instructions. Oxidation/fermentation of glucose and respiration on fumarate, nitrate and nitrite were studied according to the procedures described by Mata et al. (2002) by using MH medium (Quesada et al., 1983) with $7.5 \%$ sea salts solution (Rodriguez-Valera et al., 1981) as the basal medium. Nutritional tests were performed by using classical methods (Ventosa et al., 1982) in modified Koser medium (Koser, 1923) [containing $\left(\mathrm{l}^{-1}\right)$ : $50 \mathrm{~g}$ $\mathrm{NaCl}, 2 \mathrm{~g} \mathrm{KCl}, 0.2 \mathrm{~g} \mathrm{MgSO}_{4} \cdot 7 \mathrm{H}_{2} \mathrm{O}, 1 \mathrm{~g} \mathrm{KNO}_{3}, 1 \mathrm{~g}$ $\left(\mathrm{NH}_{4}\right)_{2} \mathrm{HPO}_{4}$ and $\left.0.5 \mathrm{~g} \mathrm{KH}_{2} \mathrm{PO}_{4}\right]$. When amino acids were used as substrates, the basal medium contained neither $\mathrm{KNO}_{3}$ nor $\left(\mathrm{NH}_{4}\right)_{2} \mathrm{HPO}_{4}$. Organic compounds used as sole source of carbon and energy or as sole source of carbon, nitrogen and energy were tested at $0.2 \%(\mathrm{w} / \mathrm{v})$. Motility, antimicrobial susceptibility and catalase and oxidase activities were determined as described by Chen et al. (2007b). Other enzymic activities and acid production from carbohydrates were carried out by using the API 20E, API ZYM and API 50CH systems (bioMérieux) according to the manufacturer's instructions, except that the suspension medium was supplemented with artificial seawater [containing (w/v): $5 \% \quad \mathrm{NaCl}, \quad 0.59 \%$ $\mathrm{MgSO}_{4} \cdot 7 \mathrm{H}_{2} \mathrm{O}, 0.45 \mathrm{MgCl}_{2} \cdot 6 \mathrm{H}_{2} \mathrm{O}, 0.06 \mathrm{KCl}$ and 0.13 $\mathrm{CaCl}_{2}$; (Levring, 1946)]. Morphological, cultural, physiological and biochemical characteristics of strain YIM kkny $3^{\mathrm{T}}$ are summarized in the species description below and in Table 1.

DNA was isolated according to the method of Hopwood et al. (1985) and the $\mathrm{G}+\mathrm{C}$ content was determined by using the HPLC method (Mesbah et al., 1989). Genomic DNA extraction, PCR-mediated amplification of the $16 \mathrm{~S}$ rRNA gene and purification of PCR products were performed as described by Cui et al. (2001). Multiple alignments with sequences of the most closely related strains and the determination of the levels of similarity between sequences were carried out by using CLUSTAL_X (Thompson et al., 1997). Distances were calculated by using distance options according to the Kimura twoparameter model (Kimura, 1980). Phylogenetic trees were constructed by using three tree-making algorithms, the neighbour-joining (Saitou \& Nei, 1987), maximumlikelihood (Felsenstein, 1981) and minimum-evolution (Felsenstein, 1997) methods, contained within the MEGA version 3.1 software package (Kumar et al., 2004). Confidence values for the branches of phylogenetic trees were determined by using bootstrap analysis (Felsenstein, 1985) based on 1000 resamplings. DNA-DNA hybridization was carried out by using photobiotin-labelled probes in microplate wells as described by Ezaki et al. (1989). A microplate spectrofluorometer (Gemini XPS; Molecular Devices) was employed for fluorescence measurements.

The genomic DNA G + C content of strain YIM kkny3 $3^{\mathrm{T}}$ was $40.9 \mathrm{~mol} \%$. The almost-complete $16 \mathrm{~S}$ rRNA gene sequence (1562 bp) of the organism was determined. Phylogenetic analysis based on 16S rRNA gene sequences revealed that strain YIM kkny3 ${ }^{\mathrm{T}}$ was related closely to members of the genus Virgibacillus, with sequence similarities of between $95.0 \%$ (to V. koreensis $\mathrm{BH} 30097^{\mathrm{T}}$ ) and $97.1 \%$ (to V. olivae $\mathrm{E}_{30} 8^{\mathrm{T}}$ ). Strain YIM kkny3 $3^{\mathrm{T}}$ showed 16S rRNA gene sequence similarities of 97.0, 96.8, 96.4 and $96.2 \%$ to the type strains of $V$. marismortui, V. kekensis, $V$. proomii and $V$. halodenitrificans, respectively. In the neighbour-joining, maximum-parsimony and minimumevolution phylogenetic trees, strain YIM kkny $3^{\mathrm{T}}$ and the type strain of $V$. salexigens (16S rRNA gene sequence similarity of $95.5 \%$ ) formed a subline supported by a low bootstrap resampling value (Fig. 1 and supplementary Fig. S1 available in IJSEM Online). Levels of DNA-DNA relatedness between strain YIM kkny $3^{\mathrm{T}}$ and the type strains of $V$. olivae, $V$. marismortui and $V$. kekensis were 12.4, 10.6 and $15.7 \%$, respectively. These values were well below the threshold value of $70 \%$ recommended by Wayne et al. (1987) for assigning strains to the same species. It is therefore evident, based on phylogenetic analysis and 
Table 1. Differential characteristics between strain YIM kkny3 ${ }^{\top}$ and recognized species of the genus Virgibacillus

Taxa: 1, strain YIM kkny3 ${ }^{\mathrm{T}}$ (data from the present study); 2, V. olivae (Quesada et al., 2007); 3, V. marismortui (Arahal et al., 1999, 2000; Heyrman et al., 2003); 4, V. kekensis (Chen et al., 2008a); 5, V. halodenitrificans (Yoon et al., 2004); 6, V. carmonensis (Heyrman et al., 2003); 7, V. proomii (Heyndrickx et al., 1999; Heyrman et al., 2003); 8, V. pantothenticus (Heyndrickx et al., 1999; Heyrman et al., 2003); 9, V. dokdonensis (Yoon et al., 2005); 10, V. necropolis (Heyrman et al., 2003); 11, V. salexigens (Wainø et al., 1999; Heyrman et al., 2003); 12, V. koreensis (Lee et al., 2006); 13, V. halophilus (An et al., 2007); 14, V. chiguensis (Wang et al., 2008). +, Positive; -, negative; v, variable; w, weakly positive; ND, no data available. Data in parentheses are for the type strain. Cells of all taxa are rod-shaped, motile, produce spores in swollen sporangia and are positive for catalase and growth with $10 \%(\mathrm{w} / \mathrm{v}) \mathrm{NaCl}$.

\begin{tabular}{|c|c|c|c|c|c|c|c|c|c|c|c|c|c|c|}
\hline Characteristic & 1 & 2 & 3 & 4 & 5 & 6 & 7 & 8 & 9 & 10 & 11 & 12 & 13 & 14 \\
\hline Spore shape ${ }^{*}$ & $\mathrm{E}$ & $S, E$ & $\mathrm{E}$ & E, $S$ & E & $E, S$ & S, E & S, E & S, E & $\mathrm{E}$ & $\mathrm{E}$ & E & $\mathrm{E}$ & S, E \\
\hline Spore position $\dagger$ & ST & $\mathrm{T}, \mathrm{sT}$ & $\mathrm{T}, \mathrm{ST}$ & $\mathrm{T}$ & $\mathrm{T}, \mathrm{sT}$ & ST & $\mathrm{T}, \mathrm{ST}$ & $\mathrm{T}, \mathrm{ST}$ & $\mathrm{T}, \mathrm{ST}$ & C, ST, T & C, ST, T & $\mathrm{T}$ & ST & $\mathrm{T}, \mathrm{TS}$ \\
\hline $\begin{array}{l}\text { Temperature range } \\
\left({ }^{\circ} \mathrm{C}\right)\end{array}$ & $10-55$ & $20-45$ & $10-45$ & $10-50$ & $15-50$ & $10-40$ & $15-50$ & $15-50$ & $15-50$ & $10-40$ & $15-45$ & $10-45$ & $5-45$ & $15-55$ \\
\hline \multicolumn{15}{|l|}{ Growth with/at: } \\
\hline $0 \% \mathrm{NaCl}$ & - & + & - & + & - & - & $\mathrm{ND}$ & ND & + & $\mathrm{w}$ & - & - & + & + \\
\hline $\mathrm{pH} 10$ & + & - & - & + & - & ND & - & - & ND & $\mathrm{ND}$ & + & - & + & - \\
\hline \multicolumn{15}{|l|}{ Hydrolysis of: } \\
\hline Aesculin & + & $\mathrm{v}(+)$ & $\mathrm{v}(-)$ & - & + & $\mathrm{w}$ & + & + & + & - & + & + & ND & + \\
\hline Casein & - & $\mathrm{v}(+)$ & + & - & + & + & + & + & + & + & + & $\mathrm{ND}$ & $\mathrm{ND}$ & + \\
\hline Gelatin & + & + & + & - & + & - & $\mathrm{V}$ & + & + & $\mathrm{W}$ & + & - & ND & + \\
\hline Starch & - & + & - & + & - & ND & $\mathrm{ND}$ & $\mathrm{ND}$ & + & $\mathrm{ND}$ & - & $\mathrm{ND}$ & ND & - \\
\hline Urea & - & $\mathrm{ND}$ & + & - & - & - & - & - & - & $\mathrm{w}$ & - & - & - & ND \\
\hline Anaerobic growth & - & - & + & - & - & - & + & + & + & - & - & + & - & + \\
\hline Nitrate reduction & + & + & + & + & + & + & - & V & - & + & - & - & + & + \\
\hline $\mathrm{H}_{2} \mathrm{~S}$ production & - & $\mathrm{ND}$ & - & - & + & - & - & $\mathrm{V}$ & - & - & + & - & - & - \\
\hline \multicolumn{15}{|l|}{ Acid production from: } \\
\hline D-Galactose & - & - & + & - & - & - & + & - & + & - & $\mathrm{w}$ & - & $\mathrm{w}$ & $\mathrm{w}$ \\
\hline D-Glucose & + & - & + & + & + & - & + & - & + & $\mathrm{w}$ & $\mathrm{w}$ & $\mathrm{w}$ & + & + \\
\hline D-Fructose & + & + & $\mathrm{v}(+)$ & - & + & - & + & - & + & $\mathrm{w}$ & $\mathrm{w}$ & + & + & + \\
\hline D-Mannitol & - & - & + & $\mathrm{w}$ & - & - & + & - & - & - & - & - & + & + \\
\hline D-Mannose & + & - & + & - & + & - & + & - & + & $\mathrm{w}$ & $\mathrm{w}$ & - & + & + \\
\hline $\begin{array}{l}\text { DNA G + C content } \\
(\mathrm{mol} \%)\end{array}$ & 40.9 & $30.7-33.4$ & $38-39$ & 41.8 & $39.0-42.8$ & 38.9 & $36.8-37.0$ & $36.9-38.3$ & 36.7 & 37.3 & $36.3-39.5$ & 41 & 42.6 & 37.3 \\
\hline
\end{tabular}

${ }^{\star}$ E, ellipsoidal; s, spherical.

$\dagger \mathrm{C}$, central; ST, subterminal; $\mathrm{T}$, terminal.

DNA-DNA hybridization data, that strain YIM kkny3 ${ }^{\mathrm{T}}$ represents a novel species of the genus Virgibacillus (Wayne et al., 1987; Stackebrandt \& Goebel, 1994).

Amino-acid and sugar analyses of whole-cell hydrolysates were performed as described by Hasegawa et al. (1983) and Staneck \& Roberts (1974), respectively. Polar lipids were extracted according to the method of Minnikin et al. (1984) and were identified by two-dimensional TLC and spraying with appropriate detection reagents (Minnikin et al., 1984; Komagata \& Suzuki, 1987). Isoprenoid quinones were analysed by HPLC as described by Groth et al. (1996). Fatty acids were determined for the new isolate as well as for three reference strains, $V$. marismortui DSM $12325^{\mathrm{T}}, V$. halodenitrificans DSM $10037^{\mathrm{T}}$ and $V$. kekensis YIM kkny16 ${ }^{\mathrm{T}}$, as described by Sasser (1990), by using the Microbial Identification system (MIDI; Microbial ID). Cells for this purpose were grown in MB supplemen- ted with $5 \%(\mathrm{w} / \mathrm{v}) \mathrm{NaCl}(\mathrm{pH} 7.5)$ in flasks on a rotary shaker (shaking at 200 r.p.m.) at $37^{\circ} \mathrm{C}$ for 3 days.

Chemotaxonomic data for strain YIM $k$ kny $3^{\mathrm{T}}$ were consistent with its assignment to the genus Virgibacillus (Heyndrickx et al., 1998; Heyrman et al., 2003). The peptidoglycan of strain YIM kkny3 $3^{\mathrm{T}}$ contained mesodiaminopimelic acid. Galactose, glucose and ribose were present in the whole-cell hydrolysates. The fatty acid profile of strain YIM kkny $3^{\mathrm{T}}$ was similar to those of members of the genus Virgibacillus (see Supplementary Table S1 in IJSEM Online). The major fatty acids of strain YIM kkny $3^{\mathrm{T}}$ were anteiso- $\mathrm{C}_{15: 0}(58.9 \%$ of the total $)$ and anteiso- $\mathrm{C}_{17: 0}$ $(17.3 \%)$. Menaquinone 7 (MK-7; 97.7\%) was the predominant menaquinone, with MK-6 (2.0\%) and MK$8(0.3 \%)$ present in trace amounts. Diphosphatidylglycerol, phosphatidylglycerol, phosphatidylethanolamine and an unknown phospholipid were found as polar lipids. 


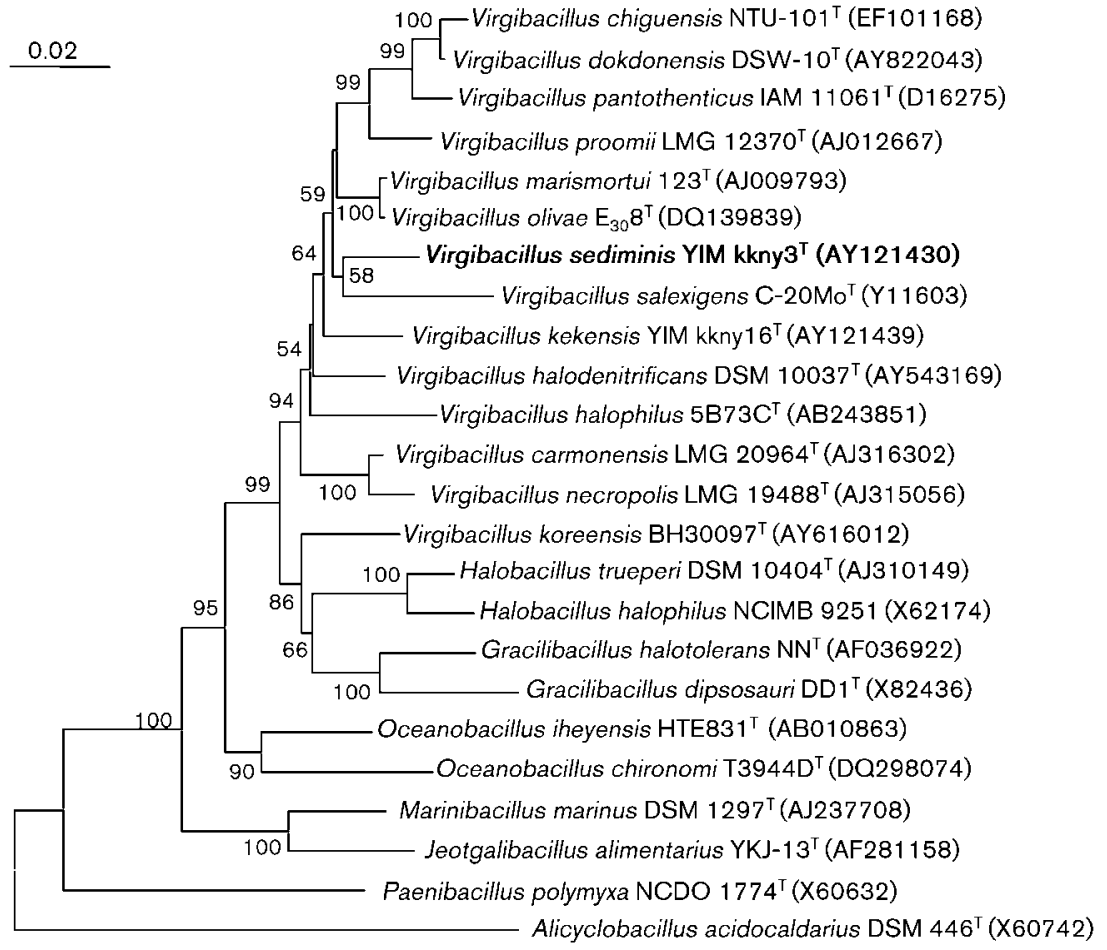

Fig. 1. Phylogenetic dendrogram based on 16S rRNA gene sequence analysis and constructed according to the neighbour-joining method showing the position of strain YIM kkny $3^{\top}$ among its closest neighbours. Bootstrap values (percentages of 1000 replications) of $>50 \%$ are shown at nodes. Bar, 2 substitutions per 100 nt.
The results of the phylogenetic analysis and chemotaxonomic studies supported the view that strain YIM kkny $3^{\mathrm{T}}$ should be assigned to the genus Virgibacillus (Heyndrickx et al., 1998; Heyrman et al., 2003). However, it could be distinguished from recognized species of the genus based on a number of phenotypic properties (Table 1) and by its discriminative fatty acid profile (Supplementary Table S1), although the latter may partly have resulted from the different culture conditions employed. The comparatively wide growth temperature range for strain YIM kkny3 ${ }^{\mathrm{T}}$ (10$55{ }^{\circ} \mathrm{C}$ ) (Table 1) and the high ratio of anteiso- to isobranched fatty acids in its fatty acid profile (Supplementary Table S1) clearly differentiated the new isolate from recognized species of the genus Virgibacillus. Strain YIM kkny $3^{\mathrm{T}}$ also differed from its closest phylogenetic relative, $V$. olivae, based on its ability to grow at $\mathrm{pH} 10$ and to produce acids from D-glucose and D-mannose, and its inability to grow in the absence of $\mathrm{NaCl}$ or to hydrolyse starch (Table 1). In addition, strain YIM kkny3 ${ }^{\mathrm{T}}$ could be differentiated from the type strain of $V$. olivae based on its much higher genomic DNA $\mathrm{G}+\mathrm{C}$ content $(>7 \mathrm{~mol} \%$ difference, Table 1) and its distinct cellular fatty acid pattern (the ratio of anteiso- to iso-branched fatty acids in the fatty acid profile of strain YIM kkny3 $3^{\mathrm{T}}$ was approximately nine times higher than that of the type strain of $V$. olivae; Supplementary Table S1). On the basis of the results of phylogenetic analysis, genotypic data (levels of DNADNA relatedness and genomic DNA $\mathrm{G}+\mathrm{C}$ content), phenotypic characteristics and chemotaxonomic distinctiveness presented here, we suggest that strain YIM kkny $3^{\mathrm{T}}$ represents a novel species of the genus Virgibacillus, for which the name Virgibacillus sediminis sp. nov. is proposed.

\section{Description of Virgibacillus sediminis sp. nov.}

Virgibacillus sediminis (se.di'min.is. L. gen. n. sediminis of sediment).

Cells are Gram-positive, catalase- and oxidase-positive, strictly aerobic rods, approximately $0.4-0.7 \mu \mathrm{m}$ wide and 2.5-4.0 $\mu \mathrm{m}$ long, occurring singly, in pairs or in short chains. Cells are motile by means of peritrichous flagella. They bear ellipsoidal endospores that lie in subterminally swollen sporangia. After 3 days on MA supplemented with $5 \%(\mathrm{w} / \mathrm{v}) \mathrm{NaCl}$ at $37{ }^{\circ} \mathrm{C}$, colonies are $2-3 \mathrm{~mm}$ in diameter, circular to slightly irregular, raised, translucent and creamy white to pale yellow. No soluble pigments are produced. Growth occurs with 1-20\% (w/v) total salts (optimum, 5$10 \%$ ) and at $10-55{ }^{\circ} \mathrm{C}$ (optimum, 35-40 ${ }^{\circ} \mathrm{C}$ ) and $\mathrm{pH} 6.0-$ 10.5 (optimum, $\mathrm{pH} 7.5-8.0$ ). Unable to grow with $\mathrm{NaCl}$ as sole salt. Aesculin and gelatin are hydrolysed, but casein, starch, Tweens (20, 40, 60 and 80) and urea are not. Positive for nitrate reduction and oxidation of glucose, but negative for fermentation of glucose, nitrite reduction, $\mathrm{H}_{2} \mathrm{~S}$ and indole production, and methyl red and VogesProskauer tests. Respiration on nitrate, nitrite and fumarate under anaerobic conditions is not observed. Acids are produced from cellobiose, D-glucose, D-fructose, D-mannose and turanose (API 50CH); other organic substrates included in the API $50 \mathrm{CH}$ panels are not metabolized. The following compounds are utilized as sole 
source of carbon and energy or sole source of carbon, nitrogen and energy: cellobiose, dextrin, D-glucose, maltose, D-mannose, D-ribose, trehalose, acetate, gluconate and L-alanine. The following substances are not utilized: Larabinose, D-fructose, D-galactose, D-lactose, melezitose, melibiose, raffinose, L-rhamnose, D-salicin, sucrose, Dxylose, adonitol, D-arabitol, glycerol, myo-inositol, Dmannitol, D-sorbitol, butyrate, citrate, fumarate, propionate, succinate, L-asparagine, L-cysteine, L-glutamic acid, Dglycine, L-histidine, hydroxy-L-proline, L-isoleucine, Lleucine, L-methionine, L-proline, L-serine and L-valine. Constitutive enzymes expressed are acid phosphatase, esterase (C4), gelatinase, $\alpha$-glucosidase, $\beta$-glucuronidase, leucine arylamidase and naphthol-AS-BI-phosphohydrolase, but alkaline phosphatase, $N$-acetyl- $\beta$-glucosaminidase, arginine dihydrolase, $\alpha$-chymotrypsin, cystine arylamidase, esterase lipase (C8), $\alpha$-fucosidase, $\alpha$-galactosidase, $\beta$ galactosidase, $\beta$-glucosidase, lipase (C14), lysine decarboxylase, $\alpha$-mannosidase, ornithine decarboxylase, tryptophan deaminase, trypsin and valine arylamidase are not produced (API 20E and ZYM). Cells are resistant to ampicillin $(30 \mu \mathrm{g})$, gentamicin $(10 \mu \mathrm{g})$ and nalidixic acid $(20 \mu \mathrm{g})$, but susceptible to chloramphenicol $(30 \mu \mathrm{g})$, kanamycin $(30 \mu \mathrm{g})$, licomycin $(2 \mu \mathrm{g})$, novobiocin $(30 \mu \mathrm{g})$, polymyxin B $(30 \mu \mathrm{g})$, rifampicin $(5 \mu \mathrm{g})$, streptomycin $(10 \mu \mathrm{g})$ and tetracycline $(30 \mu \mathrm{g})$. Whole-cell hydrolysates contain meso-diaminopimelic acid and galactose, glucose and ribose. The predominant menaquinone is MK-7. The polar lipids consist of diphosphatidylglycerol, phosphatidylglycerol, phosphatidylethanolamine and an unknown phospholipid. The major cellular fatty acids of the type strain (comprising $86.2 \%$ of the total) are anteiso- $\mathrm{C}_{15: 0}$ and anteiso- $\mathrm{C}_{17: 0}$. The DNA $\mathrm{G}+\mathrm{C}$ content of the type strain is $40.9 \mathrm{~mol} \%$.

The type strain, YIM kkny $3^{\mathrm{T}}\left(=\right.$ CCTCC AA $207023^{\mathrm{T}}=$ DSM $19797^{\mathrm{T}}=$ KCTC $13193^{\mathrm{T}}$ ), was isolated from a saline sediment sample collected from the Keke salt lake in the Qaidam Basin in Qinghai Province, north-west China.

\section{Acknowledgements}

This study was supported by grants from the National Natural Science Foundation of China (NSFC) (30660004, 30460004, 30760006, 30860013), Jishou University (jsdxkyzz200801, 07JDPHE148, 07JDPHE150, 07JDPHE151, 07JDPHE153), the Ministry of Science and Technology of China (863 Program, no. 2007AA021306; 2006BAE01A01-9), the Ministry of Environmental Protection of China (2008zx07102-004), and the Yunnan Provincial Sciences and Technology Department (2005PY01-1, 2006C0006M) and Yunnan University (2008BY005). We thank Ms Li Zhang and Mr Huai-Dong Xiao for their excellent technical assistance.

\section{References}

An, S.-Y., Asahara, M., Goto, K., Kasai, H. \& Yokota, A. (2007). Virgibacillus halophilus sp. nov., spore-forming bacteria isolated from soil in Japan. Int J Syst Evol Microbiol 57, 1607-1611.

Arahal, D. R., Marquez, M. C., Volcani, B. E., Schleifer, K. H. \& Ventosa, A. (1999). Bacillus marismortui sp. nov., a new moderately halophilic species from the Dead Sea. Int J Syst Bacteriol 49, 521-530.
Arahal, D. R., Marquez, M. C., Volcani, B. E., Schleifer, K. H. \& Ventosa, A. (2000). Reclassification of Bacillus marismortui as Salibacillus marismortui comb. nov. Int J Syst Evol Microbiol 50, 1501-1503.

Atlas, R. M. (1993). Handbook of Microbiological Media. Edited by L. C. Parks. Boca Raton, FL: CRC Press.

Chen, Y.-G., Jiang, Y., Li, W.-J., Cui, X.-L. \& Xu, L.-H. (2007a). Microbial diversity and screening of antitumor activity of actinomycete strains from saline and alkaline environments in the Qinghai Province, PR China. Acta Microbiol Sin 47, 757-762.

Chen, Y.-G., Cui, X.-L., Pukall, R., Li, H.-M., Yang, Y.-L., Xu, L.-H., Wen, M.-L., Peng, Q. \& Jiang, C.-L. (2007b). Salinicoccus kunmingensis sp. nov., a moderately halophilic bacterium isolated from a salt mine in Yunnan, south-west China. Int J Syst Evol Microbiol 57, 2327-2332.

Chen, Y.-G., Cui, X.-L., Fritze, D., Chai, L.-H., Schumann, P., Wen, M.-L., Wang, Y.-X., Xu, L.-H. \& Jiang, C.-L. (2008a). Virgibacillus kekensis sp. nov., a moderately halophilic bacterium isolated from a salt lake in China. Int J Syst Evol Microbiol 58, 647-653.

Chen, Y.-G., Cui, X.-L., Kroppenstedt, R. M., Stackebrandt, E., Wen, M.-L., Xu, L.-H. \& Jiang, C.-L. (2008b). Nocardiopsis quinghaiensis sp. nov., isolated from saline soil in China. Int J Syst Evol Microbiol 58, 699-705.

Chen, Y.-G., Cui, X.-L., Zhang, Y.-Q., Li, W.-J., Wang, Y.-X., Kim, C.-J., Lim, J.-M., Xu, L.-H. \& Jiang, C.-L. (2008c). Salinimicrobium terrae sp. nov., isolated from saline soil, and emended description of the genus Salinimicrobium. Int J Syst Evol Microbiol 58, 2501-2501.

Chen, Y.-G., Cui, X.-L., Zhang, Y.-Q., Li, W.-J., Wang, Y.-X., Xu, L.-H., Peng, Q., Wen, M.-L. \& Jiang, C.-L. (2008d). Gracilibacillus halophilus sp. nov., a moderately halophilic bacterium isolated from saline soil. Int J Syst Evol Microbiol 58, 2403-2408.

Cowan, S. T. \& Steel, K. J. (1965). Manual for the Identification of Medical Bacteria. London: Cambridge University Press.

Cui, X.-L., Mao, P.-H., Zeng, M., Li, W.-J., Zhang, L.-P., Xu, L.-H. \& Jiang, C.-L. (2001). Streptomonospora salina gen. nov., sp. nov., a new member of the family Nocardiopsaceae. Int J Syst Evol Microbiol 51, 357-363.

Doetsch, R. N. (1981). Determinative methods of light microscopy. In Manual of Methods for General Bacteriology, pp. 21-33. Edited by P. Gerhardt, R. G. E. Murray, R. N. Costilow, E. W. Nester, W. A. Wood, N. R. Krieg \& G. H. Phillips. Washington, DC: American Society for Microbiology.

Ezaki, T., Hashimoto, Y. \& Yabuuchi, E. (1989). Fluorometric deoxyribonucleic acid-deoxyribonucleic acid hybridization in microdilution wells as an alternative to membrane filter hybridization in which radioisotopes are used to determine genetic relatedness among bacterial strains. Int J Syst Bacteriol 39, 224-229.

Felsenstein, J. (1981). Evolutionary trees from DNA sequences: a maximum likelihood approach. J Mol Evol 17, 368-376.

Felsenstein, J. (1985). Confidence limits on phylogenies: an approach using the bootstrap. Evolution 39, 783-791.

Felsenstein, J. (1997). An alternative least-squares approach to inferring phylogenies from pairwise distances. Syst Biol 46, 101-111.

Gregersen, T. (1978). Rapid method for distinction of Gram-negative from Gram-positive bacteria. Eur J Appl Microbiol Biotechnol 5, 123-127.

Groth, I., Schumann, P., Weiss, N., Martin, K. \& Rainey, F. A. (1996). Agrococcus jenensis gen. nov., sp. nov., a new genus of actinomycetes with diaminobutyric acid in the cell wall. Int J Syst Bacteriol 46, 234-239.

Hasegawa, T., Takizawa, M. \& Tanida, S. (1983). A rapid analysis for chemical grouping of aerobic actinomycetes. J Gen Appl Microbiol 29, 319-322. 
Heyndrickx, M., Lebbe, L., Kersters, K., De Vos, P., Forsyth, G. \& Logan, N. A. (1998). Virgibacillus: a new genus to accommodate Bacillus pantothenticus (Proom and Knight 1950). Emended description of Virgibacillus pantothenticus. Int J Syst Bacteriol 48, 99-106.

Heyndrickx, M., Lebbe, L., Kersters, K., Hoste, B., De Wachter, R., De Vos, P., Forsyth, G. \& Logan, N. A. (1999). Proposal of Virgibacillus proomii sp. nov. and emended description of Virgibacillus pantothenticus (Proom and Knight 1950) Heyndrickx et al. 1998. Int J Syst Bacteriol 49, 1083-1090.

Heyrman, J., Logan, N. A., Busse, H.-J., Balcaen, A., Lebbe, L., Rodriguez-Diaz, M., Swings, J. \& De Vos, P. (2003). Virgibacillus carmonensis sp. nov., Virgibacillus necropolis sp. nov. and Virgibacillus picturae sp. nov., three novel species isolated from deteriorated mural paintings, transfer of the species of the genus Salibacillus to Virgibacillus, as Virgibacillus marismortui comb. nov. and Virgibacillus salexigens comb. nov., and emended description of the genus Virgibacillus. Int J Syst Evol Microbiol 53, 501-511.

Hopwood, D. A., Bibb, M. J., Chater, K. F., Kieser, T., Bruton, C. J., Kieser, H. M., Lydiate, D. J., Smith, C. P. \& Ward, J. M. (1985). Preparation of chromosomal, plasmid and phage DNA. In Genetic Manipulation of Streptomyces: a Laboratory Manual, pp. 79-80. Norwich: John Innes Foundation.

Kimura, M. (1980). A simple method for estimating evolutionary rates of base substitutions through comparative studies of nucleotide sequences. J Mol Evol 16, 111-120.

Komagata, K. \& Suzuki, K. (1987). Lipid and cell-wall analysis in bacterial systematics. Methods Microbiol 19, 161-207.

Koser, S. A. (1923). Utilization of the salts of organic acids by the colon-aerogenes group. J Bacteriol 8, 493-520.

Kumar, S., Tamura, K. \& Nei, M. (2004). MEGA3: integrated software for molecular evolutionary genetics analysis and sequence alignment. Brief Bioinform 5, 150-163.

Lee, J.-S., Lim, J.-M., Lee, K. C., Lee, J.-C., Park, Y.-H. \& Kim, C.-J. (2006). Virgibacillus koreensis sp. nov., a novel bacterium from a salt field, and transfer of Virgibacillus picturae to the genus Oceanobacillus as Oceanobacillus picturae comb. nov. with emended descriptions. Int J Syst Evol Microbiol 56, 251-257.

Levring, T. (1946). Some culture experiments with Ulva and artificial seawater. K Fysiogr Sallsk Lund Forhandl 16, 45-56.

Mata, J. A., Martínez-Cánovas, J., Quesada, E. \& Béjar, V. (2002). A detailed phenotypic characterization of the type strains of Halomonas species. Syst Appl Microbiol 25, 360-375.

Mesbah, M., Premachandran, U. \& Whitman, W. B. (1989). Precise measurement of the $\mathrm{G}+\mathrm{C}$ content of deoxyribonucleic acid by highperformance liquid chromatography. Int J Syst Bacteriol 39, 159-167.

Minnikin, D. E., O'Donnell, A. G., Goodfellow, M., Alderson, G., Athalye, M., Schaal, A. \& Parlett, J. H. (1984). An integrated procedure for the extraction of bacterial isoprenoid quinones and polar lipids. J Microbiol Methods 2, 233-241.

Quesada, E., Ventosa, A., Rodriguez-Valera, F., Megias, L. \& RamosCormenzana, A. (1983). Numerical taxonomy of moderately halophilic Gram-negative bacteria from hypersaline soils. J Gen Microbiol 129, 2649-2657.

Quesada, T., Aguilera, M., Morillo, J. A., Ramos-Cormenzana, A. \& Monteoliva-Sánchez, M. (2007). Virgibacillus olivae sp. nov., isolated from waste wash-water from processing of Spanish-style green olives. Int J Syst Evol Microbiol 57, 906-910.

Rodriguez-Valera, F., Ruiz-Berraquero, F. \& Ramos-Cormenzana, A. (1981). Characteristics of the heterotrophic bacterial populations in hypersaline environments of different salt concentrations. Microb Ecol 7, 235-243.

Saitou, N. \& Nei, M. (1987). The neighbor-joining method: a new method for reconstructing phylogenetic trees. Mol Biol Evol 4, 406425.

Sasser, M. (1990). Identification of bacteria by gas chromatography of cellular fatty acids, MIDI Technical Note 101. Newark, DE: MIDI Inc.

Smibert, R. M. \& Krieg, N. R. (1994). Phenotypic characterization. In Methods for General and Molecular Bacteriology, pp. 607-654. Edited by P. Gerhardt, R. G. E. Murray, W. A. Wood \& N. R. Krieg. Washington, DC: American Society for Microbiology.

Stackebrandt, E. \& Goebel, B. M. (1994). Taxonomic note: a place for DNA-DNA reassociation and 16S rRNA sequence analysis in the present species definition in bacteriology. Int J Syst Bacteriol 44, 846-849.

Staneck, J. L. \& Roberts, G. D. (1974). Simplified approach to identification of aerobic actinomycetes by thin-layer chromatography. Appl Microbiol 28, 226-231.

Thompson, J. D., Gibson, T. J., Plewniak, F., Jeanmougin, F. \& Higgins, D. G. (1997). The CLUSTAL_X windows interface: flexible strategies for multiple sequence alignment aided by quality analysis tools. Nucleic Acids Res 25, 4876-4882.

Ventosa, A., Quesada, E., Rodriguez-Valera, F., Ruiz-Berraquero, F. \& Ramos-Cormenzana, A. (1982). Numerical taxonomy of moderately halophilic Gram-negative rods. J Gen Microbiol 128, 1959-1968.

Wainø, M., Tindall, B. J., Schumann, P. \& Ingvorsen, K. (1999). Gracilibacillus gen. nov., with description of Gracilibacillus halotolerans gen. nov., sp. nov.; transfer of Bacillus dipsosauri to Gracilibacillus dipsosauri comb. nov., and Bacillus salexigens to the genus Salibacillus gen. nov., as Salibacillus salexigens comb. nov. Int J Syst Bacteriol 49, 821-831.

Wang, C.-Y., Chang, C.-C., Ng, C. C., Chen, T.-W. \& Shyu, Y.-T. (2008). Virgibacillus chiguensis sp. nov., a novel halophilic bacterium isolated from Chigu, a previously commercial saltern located in southern Taiwan. Int J Syst Evol Microbiol 58, 341-345.

Wayne, L. G., Brenner, D. J., Colwell, R. R., Grimont, P. A. D., Kandler, O., Krichevsky, M. I., Moore, L. H., Moore, W. E. C., Murray, R. G. E. \& other authors (1987). International Committee on Systematic Bacteriology. Report of the ad hoc committee on reconciliation of approaches to bacterial systematics. Int $J$ Syst Bacteriol 37, 463-464.

Yoon, J.-H., Oh, T.-K. \& Park, Y.-H. (2004). Transfer of Bacillus halodenitrificans Denariaz et al. 1989 to the genus Virgibacillus as Virgibacillus halodenitrificans comb. nov. Int J Syst Evol Microbiol 54, 2163-2167.

Yoon, J.-H., Kang, S.-J., Lee, S.-Y., Lee, M.-H. \& Oh, T.-K. (2005). Virgibacillus dokdonensis sp. nov., isolated from a Korean island, Dokdo, located at the edge of the East Sea in Korea. Int J Syst Evol Microbiol 55, 1833-1837. 